\title{
Pemanfaatan Teknologi Gadget terhadap Pengaruh Sosial Emosi PAUD dalam Konsep Pembelajaran Literasi Digital
}

\author{
Hilman Fauzi ${ }^{1}$ \\ ${ }^{1}$ Universitas Pendidikan Indonesia \\ Email: hilbohil@gmail.com
}

\begin{abstract}
Today's challenges are very diverse, the rapid development of technology cannot be avoided by society. It is undeniable that technology is like an obligation to be possessed by every human being uncomplicated by early childhood at this time, the many uses of technology by early childhood become a problem today. Digital literacy is an effort in empowering the community so that people can follow the movement of the times including the early childhood education at this time, education today must be able to provide innovation because the age continues to develop continuously because practical education will continue to occur and is unique for each individual and society in different situations at different times. Early childhood was born in the age of technology, they are often fascinated by games and new technologies, this greatly affects patterns of human life both in terms of thought patterns and behavior. With digital literacy learning in the early childhood stage, it is hoped that this nation can achieve the expected progress.
\end{abstract}

Keywords: Early Childhood, Digital Literacy Learning, Technology Utilization

\section{PENDAHULUAN}

Pendidikan di Indonesia saat ini sedang dalam krisis kematian, hal ini dapat dilihat dari data faktual keadaan pendidikan di Indonesia yang sedang sakit akibat penyakit apolitis, artinya pendidikan terputus dari keprihatinan sosial politik, pendidikan hanya terfokus pada keterampilan secara pragmatis, yaitu menyiapkan insan yang dapat bekerja di perusahaan-perusahaan (Herlambang, 2018; Wattimena, 2014). Pendidikan Anak Usia Dini (PAUD), yaitu pendidikan yang ditunjukan untuk anak dari 0-6 tahun, PAUD diatur dalam UU No 20 tahun 2003 tentang Sisdiknas sebagai jenjang dan jalur pendidikan memiliki kurikulum yang sama baik pada PAUD formal ataupun nonformal. Sebagai jenjang pendidikan, PAUD diseleng-garakan sebelum pendidikan selanjutnya, literasi digital salah satu yang ditunjukan untuk menyiapkan anak usia dini baik secara mental dan emosional serta aspek lainnya.

Perkembangan zaman yang semakin cepat dalam segala hal tidak terlepas dari bidang pendidikan dan teknologi. Revolusi industri 4.0 menegaskan bahwa teknologi tidak dapat dipisahkan dalam kehidupan sehari hari, karena kecepatan dampak dari terobosan teknologi sangat berkembang pesat ditengah masyarakat dan kemajuan teknologi mengubah metode juga proses pembelajaran (Diwan, 2017; Dunwill, 2016; Shwab, 2016). Hal tersebut didukung oleh data dari The Asian Parent Insight (2014), pada lingkup studi kawasan asia 
tenggara dengan melibatkan setidaknya 2.417 orang tua yang memiliki gadget dan anak-anak dengan usia 3-8 tahun pada 5 negara, yakni Singapura, Thailand, Philipina, Malaysia dan Indonesia. Dengan sejumlah sampel orang tua tersebut, diperoleh sampel 3.917 anak-anak dengan usia 3-8 tahun. Dari 98\% responden anakanak usia 3-8 tahun pengguna gadget tersebut $67 \%$ di antaranya menggunakan milik orang tua, $18 \%$ menggunakan milik saudara, dan $14 \%$ sisanya menggunakan milik sendiri. Survei ini membuktikan bahwa peminat gadget saat ini hanya untuk remaja hingga dewasa, tetapi anak anak juga. Survei tersebut menegaskan bahwa teknologi bukanlah suatu yang harus dihindari tetapi bagaimana penggunaan tersebut dimanfaatkan secara baik dan benar dalam kehidupan sehari hari ataupun dalam pembelajaran.

Sebagaimana permasalahan yang ada, untuk menjawab tantangan zaman dewasa ini dapat dengan diupayakan peningkatan literasi, Literasi dipandang sebagai kontruksi sosial dan tidak pernah netral, maksudnya adalah diperluas seiring perkembangan IPTEK dan multimedia (Abidin, 2015). Hal ini disebut dengan konsep multiliterasi. pembelajaran multiliterasi ditunjukan untuk mengembang-kan keterampilan siswa dalam literasi kritis, literasi visual, literasi media, literasi digital, dan literasi lainnya. Peningkatan literasi digital dalam pendidikan membantu memaha-mi penggunaan teknologi secara bijak, literasi digital tidak hanya bercangkupan dengan internet tapi bersangkutan dengan apa yang disediakan oleh teknologi termasuk hiburan atau aplikasi yang digemari oleh anak. Penggunaan teknologi yang dilakukan oleh anak ini mengundang beberapa perdebatan dari beberapa kalangan, dan menganggapnya sebagai suatu hal yang tabu dilakukan oleh anak-anak. Pendidikan dewasa ini diharapkan mampu mengubah stigma yang beredar tentang dampak buruk dari penggunaan teknologi baik internet ataupun non internet.

\section{HASIL DAN PEMBAHASAN}

Pembelajaran literasi digital adalah upaya memberdayakan masyarakat dalam meningkatkan kemampuan menggunakan teknologi informasi dan komunikasi. Oleh karena itu digital literasi haruslah mencangkup kemampuan dalam mempermu-dah, mengenali, mencari, menggunakan, memanfaatkan, membuat, mengomunikasikan dan juga mengevaluasi informasi yang dibutuhkan karena literasi digital bukan lagi sebuah kemewahan melainkan keharusan bagi seluruh golongan umur manusia (ICT Watch, 2017; UNESCO, 2011; UNICEF, 2018). Penjelasan tersebut menegaskan bahwa literasi digital merupakan sesuatu yang harus dipelajari dari usia dini sehingga melekat dalam diri dan juga bertujuan untuk dapat menjawab permasalahan yang dihadapi dalam penyelenggaraan pendidikan sesuai kebutuhan dan tuntutan zaman yang terus berkembang secara berkesinambungan karena praktis pendidikan akan terus-menerus terjadi dan unik bagi setiap individu dan masyarakat di dalam situasi dan waktu yang berbeda. Kondisi ini diperkuat dengan keadaan para siswa yang mana pada zaman ke zaman yang berbeda dalam ciri khasnya (Tilaar, 2012)).

Perkembangan sosial anak diperoleh dari kematangan dan kesempatan belajar dari berbagai respons lingkungan terhadap anak. Kemampuan sosial dapat diartikan kemam-puan seseorang dalam berinteraksi, bergaul, memahami dan bekerja sama dengan orang lain dalam situasi yang berbeda-beda. Melalui kegiatan bermain, proses belajar untuk menyesuaikan diri terhadap norma, moral, dan tradisi, yaitu meleburkan diri menjadi suatu kesatuan yang saling berkomunikasi dan bekerjasama (Nurmalitasari, 2015; Saputra, 2017).

Perkembangan emosional adalah kemampuan untuk memahami perasaan pada diri sendiri dan orang lain rasakan. Kemampuan emosional melatih dalam memahami bahwa kejadian atau masalah 
berbeda dengan apa yang dipikirkan, termasuk cara cepat untuk menangani masalah. Kemampuan emosional membantu juga dalam mengelola dan menyalurkan emosinya secara baik (Nurmalitasari, 2015; Saputra, 2017).

Anak usia dini dewasa ini sudah lahir pada zaman teknologi. Mereka sering terpesona oleh permainan dan teknologi baru hal ini sangat memengaruhi pola kehidupan manusia, baik dari segi pola pikir maupun perilaku. Teknologi seperti dua sisi mata uang yang sama. Media sosial ini di satu sisi bisa berdampat positif di sisi lainnya berdampak negatif. Media baru dapat menyediakan anak-anak pengalaman belajar yang inovatif dan menarik. Penggunaan gadget dalam kehidu-pan sehari-hari tidak hanya memengaruhi perilaku orang dewasa, anak-anak pun tidak luput dari pengaruh penggunaan gagdet salah satunya dalam kemampuan interaksi sosial. Sebagai bagian dari proses pendidikan, anak-anak harus dilibatkan dalam refleksi kritis tentang teknologi, sama pentingnya dengan aspek literasi digital untuk anak-anak dan juga untuk orang dewasa (Gillen, 2018; Pebriana, 2017; Silviana, 2018). Tingkat pemahaman literasi digital terbagi dalam beberapa tahapan, yaitu kompetensi dasar digital, penggunaan digital, transformasi digital (Martin \& Grudziecki, 2015; Mayers, 2013).

\section{SIMPULAN}

Literasi digital merupakan suatu keharusan pesatnya perkembangan zaman yang menuntut kita harus sesuai dengan realitas yang ada dengan mengembangkan digital dan media literasi anak-anak sejak usia dini telah diidentifikasi sebagai prasyarat penting untuk mayarakat demokratis yang efektif di Indonesia.

\section{DAFTAR PUSTAKA}

Abidin, Y. (2015). Pembelajaran Multiliterasi Sebuah Jawaban Atas
Tantangan Pendidikan Abad Ke-21

dalam Konteks Keindonesian.

Bandung: Redika Aditama.

Diwan, P. (2017). Is Education 4.0 An Imperative for Succes of 4th Industrial Revolution.

Dunwill, E. (2016). Changes that Will Shape the Classrrom of the Future: Making Education Fully Technological.

Gillen, J., \& dkk. (2018). Towards Better Understanding of The Benefits and Challenges of Digital Technologies in Homes and Early Years Setting. Policy Briefing of Digilitey Cost Action IS1410 and The Digital Childhoods SIG of The European Early Chidhood Research Association. 31 st. Digital Literacy and Young Children.

Herlambang, Y. (2018). Pedagogik: Telaah Kritis Ilmu Pendidikan dalam Multiperspektif. Bandung: Bumi Aksara.

ICT Watch. (2017). Kerangka Literasi Digital Indonesia.

Nurmalitasari, F. (2015). Perkembangan Sosial Emosi pada Anak Usia Prasekolah. Buletin Psikologi, 23(2), 103-111. https://doi.org/https://doi.org/10.221 46/bpsi.10567

Pebriana, P. . (2017). Analisis Penggunaan Gadget terhadap Kemampuan Interaksi Sosial Anak Usia Dini. Jurnal Obsesi: Journal of Early Childhood Education, 1(1), 1. https://doi.org/https://doi.org/10.310 04/obsesi.v1i1.40.

Saputra, G. ., \& dkk. (2017). Pengaruh Teknologi Informasi terhadap Kecerdasan (Intelektual, Spiritual, Emosional dan Sosial) Studi Kasu Anak-Anak. Studi Informatika: Jurnal Sistem Informasi, 10(2), 7788.

https://doi.org/https://doi.org/10.154 08/sijsi.v10i2.7755

Shwab, K. (2016). The Fourth Industrial Revolution: What It Means, How to 
Repsond.

https://doi.org/Https://Www.Weforu m. Org/Agenda/20 16/01/TheFourth-Industrial-Revolution- WhatIt-Means-And-How-To-Respond

Silviana, H. C. (2018). Pendidikan Literasi Digital di Kalangan usia Muda di Kota Bandung.

Tilaar, H. A. . (2012). Kaledioskop Pendidikan Nasional. Jakarta:
Kompas Media Nusantara.

UNESCO. (2011). Policy Brief: Digital Literacy in Education. Paris: UNESCO Institute for Information Teknologi and Education.

UNICEF. (2018). Digital Literacy for Every Child.

Wattimena, A.A, R. (2014). Filsafat sebagai Revolusi Hidup. Yogyakarta: Kansius. 